\title{
Protein from Phaleria macrocarpa Fruit Aqueous Extract Inhibits Early and Late Replication Phases of Human Herpes Virus Type-1
}

\author{
Mahmud Yusef Yusef Ismaeel ${ }^{1,2}$, Herryawan RE Dyari ${ }^{3}$, Nazlina Ibrahim ${ }^{1, *}$
}

\section{Mahmud Yusef Yusef Ismaeel ${ }^{1,2}$ Herryawan RE Dyari³, Nazlina Ibrahim $^{1, *}$}

'Department of Biological Sciences and Biotechnology, Faculty of Science and

Technology, Universiti Kebangsaan Malaysia, 43600 Bangi, Selangor, MALAYSIA ${ }^{2}$ Department of Medical Science, Abbs Community College, Hajjah, YEMEN. ${ }^{3}$ Department of Earth Science and Environmental, Faculty of Science and Technology, Universiti Kebangsaan Malaysia, 43600 Bangi, Selangor, MALAYSIA.

\section{Correspondence}

\section{Nazlina Ibrahim}

Department of Biological Sciences and Biotechnology, Faculty of Science and Technology, Universiti Kebangsaan Malaysia, 43600 Bangi, Selangor, MALAYSIA.

E-mail: nazlina@ukm.edu.my

History

- Submission Date: 26-10-2021.

- Review completed: 22-11-2021;

- Accepted Date: 01-12-2021.

DOI : 10.5530/pj.2022.14.6

Article Available online

http://www.phcogj.com/v14/i1

\section{Copyright}

(C) 2022 Phcogj.Com. This is an open access article distributed under the terms of the Creative Commons Attribution 4.0 International license.

\begin{abstract}
Background: Phaleria macrocarpa fruit is known to have protein but the antiviral activity potential has not been explored. Objective: To determine the antiviral activity of Phaleria macrocarpa fruit protein aqueous extract (PMFPAE) and the fractions against human herpesvirus type 1 (HHV-1). Methods: Protein from $P$. macrocarpa fruit aqueous extract was precipitated using ammonium sulphate and followed by fractionation on Sephadex G-25. Cytotoxicity was determined in Vero cells and followed by determination of antiviral activity by plaque reduction assay against a clinical strain of HHV-1. Effect of PMFPAE on virus replication was determined in pre-treatment, time-addition and time-removal assays. Results: PMFPAE and its fractions were non-cytotoxic to Vero cells with $50 \%$ cytotoxic concentration $\left(\mathrm{CC}_{50}\right.$ ) values ranged between $96 \pm 1.3$ to $1450 \pm 2 \mu \mathrm{g} / \mathrm{mL}$. PMFPAE have good anti-HHV-1 activity with Selective Index (SI) of 80.6 but reduces in fractions $P_{1}$ to $P_{6}$ ranging between 4.2 and 67.9. Fractions with high SI were $P_{1}$ and $\mathrm{P}_{2}$ contained high molecular weight (MW) proteins and $\mathrm{P}_{6}$ has the lowest MW suggestively peptides. Treatment with PMFPAE to host cells prior to virus infection had little effect on inhibiting HHV-1 replication. Treatment with PMFPAE affects virus early and late replication phase with plaque inhibition percentage increased during $10^{\text {th }}$ to $16^{\text {th }}$ hour post-infection. Conclusion: PMFPAE contained non-cytotoxic proteins that affects HHV-1 early and late replication phases. Proteins with high antiviral activity resides in fractions with high MW and very low MW peptides.

Key words: Phaleria macrocarpa fruit protein, Fractionation, Cytotoxicity, Anti-Human herpes virus type-1.
\end{abstract}

\section{INTRODUCTION}

Human herpes virus type-1 (HHV-1) or previously known as herpes simplex virus type-1 (HSV-1) is a human virus pathogen causing a diversity of diseases ranging from common cold sores to life-threatening encephalitis ${ }^{1}$. HHV-1 infection is extremely contagious by direct contact from person to person with the possibility of becoming widespread throughout the world. The major antiviral therapy for $\mathrm{HHV}$ is acyclovir (ACV) which is a nucleoside analogue that reduce the severity of the symptoms but does not cure the infection $^{2-3}$. The emergence of drug-resistant herpes virus strains has been associated with the increasing clinical use of ACV essentially among immunocompromised patients and in neonates ${ }^{1,4,5}$. Thus, antiviral agent exhibiting new anti-HHV-1 mechanisms is needed to overcome this threat ${ }^{6}$.

The anti-HHV-1 activity of $P$. macrocarpa has been previously determined ${ }^{7-9}$ with the aqueous extract of Phaleria macrocarpa fruit (AEPMF) exhibited in vitro antiviral activity with selective index (SI) of $17.9^{10}$. Biologically important proteins from $P$. macrocarpa have been reported in several studies ${ }^{11-12}$. However, the potential in antiviral property was not given much attention. Antiviral activity of proteins from plants have been reported with different mechanisms ${ }^{13-15}$. Fruit of $P$. macrocarpa or locally known as Mahkota Dewa is a popular medicinal plant used by the locals as tea for different kinds of remedies and has also been proven scientifically in terms of the biologically active compounds and activities ${ }^{16-20}$. With all the information put together, we hypothesize the antiviral activity of proteins from $P$. macrocarpa fruit aqueous extract specifically towards HHV-1.

\section{MATERIALS AND METHODS}

\section{Protein extraction}

Aqueous extraction of $P$. macrocarpa fruits follows the procedure according to ${ }^{10}$. Protein in the aqueous extract was precipitated using ammonium sulphate (Sigma-Aldrich) at $75 \%(\mathrm{w} / \mathrm{v})$ saturation. Pellet containing the protein was separated by centrifugation and from the supernatant. The pellet was mixed with deionized water and then dialyzed for 24 hours at room temperature using acetate buffer $(\mathrm{pH} 5)$. Freeze dried dialyzed protein designated as PMFPAE was stored at $-20^{\circ} \mathrm{C}$ until use.

\section{Gel filtration chromatography (GFC)}

Protein fractionation by GFC was employed according to ${ }^{21}$. Acetate buffer $(0.02 \mathrm{M})$ at $\mathrm{pH} 5$ as the mobile phase or elution buffer was applied to the $1.5 \times 32 \mathrm{~cm}$ Sephadex G-25 column. Flow rate of the elution buffer was set to $1 \mathrm{~mL} / 1 \mathrm{~min}$ and $2 \mathrm{~mL}$ of PMFPAE at $250 \mathrm{mg} / \mathrm{mL}$ was applied on the top of the column. The eluant ( $2 \mathrm{~mL}$ each) was collected using the fraction collector (BioRad, USA). Thirty fractions were collected and optical density (OD) at $280 \mathrm{~nm}$ were measured using a spectrophotometer (UV mini-1240, Shimadzu-Germany). The fractionation process was repeated and fractions with similar OD reading were pooled. Pooled samples $\left(\mathrm{P}_{1}\right.$ to $\left.\mathrm{P}_{6}\right)$ were freeze-dried, weighed and stored at $-20{ }^{\circ} \mathrm{C}$ until use.

Cite this article: Ismaeel MYY, Dyari HRE, Ibrahim N. Protein from Phaleria macrocarpa Fruit Aqueous Extract Inhibits Early and Late Replication Phases of Human Herpes Virus Type-1. Pharmacogn J. 2022;14(1): 39-45. 


\section{Determination of protein concentration}

Protein concentration was determined using Bradford assay ${ }^{22}$ with bovine serum albumin (BSA) as standard.

\section{Cells and viruses}

African green monkey kidney (Vero) cells and HHV-1 clinical strain were obtained from Virology Laboratory stock collection, Faculty of Science and Technology, Universiti Kebangsaan Malaysia. Vero cells were propagated in Dulbecco's Modified Eagle Medium (DMEM, Nacalai Tesque) supplemented with $5 \%$ fetal bovine serum (FBS, JR Scientific), penicillin/streptomycin $100 \mathrm{U} / \mathrm{L}$, non-essential amino acids (Nacalai Tesque) and amphostate B 20 U/L (Sigma-Aldrich, USA).

\section{Cytotoxicity assessment}

Vero cells were used in the cytotoxicity assessment ${ }^{7}$ using 3-(4, 5-dimethyl-2-thiazolyl)-2, 5 diphenyltetrazolium bromide (MTT, Sigma) as reagent. Cells were treated with PMFPAE or fractions $\mathrm{P}_{1}$ to $\mathrm{P}_{6}$ prepared by doubling dilutions in DMEM between 15.6 to $2000 \mu \mathrm{g} /$ $\mathrm{mL}$. The percentage of cell viability was calculated using the following formula:

$$
\text { Cell viability }(\%)=\frac{\text { Mean absorbance of treated cells }}{\text { Mean absorbance of untreated cells }} \times 100 \% \text { (1) }
$$

The $50 \%$ cytotoxic concentration $\left(\mathrm{CC}_{50}\right)$ defined as the concentration of test extract or fractions that kills $50 \%$ of the Vero cell population was determined by non-linear regression graph plotted with cell viability percentage as $\mathrm{y}$-axis and extract or fractions concentrations as $\mathrm{x}$-axis.

\section{Plaque Reduction Assay (PRA)}

Antiviral activity was determined by PRA according to ${ }^{7}$. Almost confluent cells were infected with HHV-1 clinical strain at $100 \mathrm{pfu} /$ well for $2 \mathrm{~h}$ at $37^{\circ} \mathrm{C}$ in $5 \% \mathrm{CO}_{2}$. Different concentrations of PMFPAE (5 to $60 \mu \mathrm{g} / \mathrm{mL}$ ) in methylcellulose (MC, $1 \%$ ) with FBS (5\%) was applied to the infected cells and incubated for $48 \mathrm{~h}$ at $37^{\circ} \mathrm{C}$. Negative control was virus infected cells mock treated with DMEM only and antiviral drug ACV (Sigma-Aldrich) serves as positive control at $4.5 \mu \mathrm{g} / \mathrm{mL}$. Plaque formation was viewed using the inverted microscope and stained plaques were counted. Plaque inhibition percentage was calculated according to the following formula;

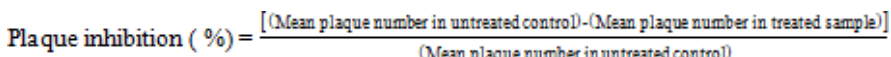
$\times 100 \%(2)$

$\mathrm{EC}_{50}$ value was determined as the extract or fraction concentrations that inhibit $50 \%$ plaques in infected cells compared to control. SI was determined from the ratio of $\mathrm{CC}_{50} / \mathrm{EC}_{50}$ values as a significant parameter to assess the antiviral activity potential. The experiments were performed in triplicates with the mean value representing three experiments.

\section{Cell Pre-treatment Assay}

Prophylactic anti-HHV-1 activity of the extract was determined in this assay according to 9 . Near to confluent Vero cells were treated with PMFPAE at 40,50 or $60 \mu \mathrm{g} / \mathrm{mL}$ or ACV $(4.5 \mu \mathrm{g} / \mathrm{mL})$ as antiviral drug control and incubated for $24 \mathrm{~h}$ in $5 \% \mathrm{CO}_{2}$ at $37^{\circ} \mathrm{C}$. Treatment was removed and cells were washed three times with phosphate-buffered saline (PBS, pH 7.4). Subsequently, cells were infected with $100 \mathrm{pfu} /$ well of HHV-1 clinical strain and incubated in $5 \% \mathrm{CO}_{2}$ at $37^{\circ} \mathrm{C}$ for 2 h. HHV-1 inoculum was discarded and applied with $1 \%$ MC mixed with $5 \%$ of FBS. Negative control includes mock pre-treated Vero cells infected with HHV-1. Plaque inhibition percentage was determined as in PRA (2).

\section{Time-Addition Assay}

The effect of PMFPAE $(60 \mu \mathrm{g} / \mathrm{mL})$ or ACV at $4.5 \mu \mathrm{g} / \mathrm{mL}$ when added at different times beginning from the time of infection was determined according to $^{23}$. Treatments were added to infected cells at time points 2 , $4,6,8,10$ and 12 hours post-infection (hpi). Negative control was cells infected with HHV-1 clinical strain and mock treated with DMEM. MC mixed with $5 \%$ of FBS was added to the treated cells and incubated in $5 \% \mathrm{CO}_{2}$ atmosphere for a further $48 \mathrm{~h}$. Plaque numbers were counted and plaque inhibition percentage was calculated according to the formula stated above (2).

\section{Time-Removal Assay}

HHV-1 infected cells were treated with PMFPAE at $60 \mu \mathrm{g} / \mathrm{mL}$ or ACV at $4.5 \mu \mathrm{g} / \mathrm{mL}$ and treatment was removed after $2,4,6,8,10,12,14$, $16,18,20,22,24,26,28$ and 30 hpi following ${ }^{23}$. Negative control was HHV-1 infected-cells and mock treated with DMEM. MC mixed with $5 \%$ of FBS was added to the treated cells and incubated in $5 \% \mathrm{CO}_{2}$ atmosphere for a further 48 hours. Plaque numbers were counted and plaque inhibition percentage was determined using equation (2).

\section{Statistical analysis}

The experiments were performed in triplicate with results were expressed as mean \pm standard deviation (SD). Statistical data analysis was conducted using one-way ANOVA by SPSS, $\mathrm{p}<0.05$ was considered significant.

\section{RESULTS AND DISCUSSIONS}

\section{PMFPAE and its Fractions}

Protein from P. macrocarpa fruit that accounts for $16 \%(\mathrm{w} / \mathrm{w})$ of the dried fruit was effectively extracted (Table 1). This is higher than previously reported by Lay et al. ${ }^{11}$ that secured at least $8.51 \%$ protein or Habib \& Ismail ${ }^{12}$ that uses three different protein extraction methods; phenol (Phe) (12.24\%), trichloroacetic acid (TCA)-acetone-phenol (TCA-A-Phe) (4.33\%), and ultrasonic (Ult) (3.57\%). Protein extraction and resolubility from fruit tissue varies according to the methods that were used. More importantly the process can be affected by the nonprotein contaminants such as polysaccharides, polyphenols, nucleic acids, terpenes, and organic acids of the fruit ${ }^{24}$. Following GFC of the PMFPAE, 30 fractions were produced with six fractions (designated as $\mathrm{P}_{1}$ to $\mathrm{P}_{6}$ ) were selected from the peaks in OD reading. GFC on Sephadex G-25 enables the isolation of low MW protein with the size of $10 \mathrm{kDa}$ or less or peptides. This is in view of proteins that may display antiviral activity has MW of approximately $10 \mathrm{kDa}^{14,25}$ and antiviral peptides MW is less than $10 \mathrm{kDa}^{26}$.

\section{Cytotoxicity and Antiviral Activity}

Table 1 shows the $\mathrm{CC}_{50}$ values of PMFPAE and fractions $\mathrm{P}_{1}$ to $\mathrm{P}_{6}$ with cell viability percentages decrease with the increase in concentration of treatment. The $\mathrm{CC}_{50}$ values less than $20 \mu \mathrm{g} / \mathrm{mL}$ are considered to be cytotoxic ${ }^{27}$. All the samples $\mathrm{CC}_{50}$ values were greater than $20 \mu \mathrm{g} /$ $\mathrm{mL}$ in Vero cells indicating safety and non-cytotoxicity of the extract and fractions. Subsequent antiviral analyses were done using the concentration below the $\mathrm{CC}_{50}$ values to ensure that any antiviral activity evaluated will not cause toxicity towards the host cells ${ }^{28}$. Concentration that inhibit $50 \%$ of $\mathrm{HHV}-1$ plaque formation or $\mathrm{EC}_{50}$ value was determined in post-infection treatment with PMFPAE or fractions $\mathrm{P}_{1}$ to $\mathrm{P}_{6}$ is summarized in Table 1 . Figure 1 displayed PMFPAE and fractions $\mathrm{P}_{1}$ to $\mathrm{P}_{6}$ antiviral activities against HHV-1 clinical strain in a dose-dependent manner. Both $\mathrm{P}_{1}$ and $\mathrm{P}_{2}$ essentially can be considered to contain high to medium MW proteins estimated from the elution order in fractionation whereas $\mathrm{P}_{6}$ may contain low MW proteins or perhaps peptides. 
Table 1: PMFPAE and fractions $P_{1}-P_{6}$ yield percentage, $50 \%$ cytotoxic concentration $\left(C_{50}\right), 50 \%$ effective concentration $\left(E C_{50}\right.$ ) against HHV-1 clinical strain and calculated selective index (SI).

\begin{tabular}{|c|c|c|c|c|c|}
\hline $\begin{array}{l}\text { Fraction } \\
\text { number }\end{array}$ & Designation & $\begin{array}{l}\text { Yield percentage } \\
(\mathrm{g} / 100 \mathrm{~g})\end{array}$ & $\begin{array}{c}\mathrm{CC}_{50} \\
(\mu \mathrm{g} / \mathrm{mL})\end{array}$ & $\begin{array}{c}E C_{50} \\
(\mu \mathrm{g} / \mathrm{mL})\end{array}$ & SI \\
\hline- & PMFPAE & 16.0 & $1450 \pm 2.0$ & $18 \pm 1.2$ & 80.6 \\
\hline 9 & $\mathrm{P}_{1}$ & 5.3 & $950 \pm 1.9$ & $14 \pm 0.5$ & 67.9 \\
\hline 12 & $\mathrm{P}_{2}$ & 6.8 & $625 \pm 1.4$ & $13 \pm 0.8$ & 48.1 \\
\hline 21 & $\mathrm{P}_{3}$ & 5.2 & $240 \pm 2.1$ & $27 \pm 0.7$ & 8.9 \\
\hline 23 & $\mathrm{P}_{4}$ & 7.5 & $96 \pm 1.3$ & $23 \pm 0.9$ & 4.2 \\
\hline 26 & $\mathrm{P}_{5}$ & 7.3 & $433 \pm 1.6$ & $28 \pm 1.1$ & 15.5 \\
\hline 29 & $\mathrm{P}_{6}$ & 6.0 & $630 \pm 1.8$ & $13 \pm 0.6$ & 48.5 \\
\hline
\end{tabular}

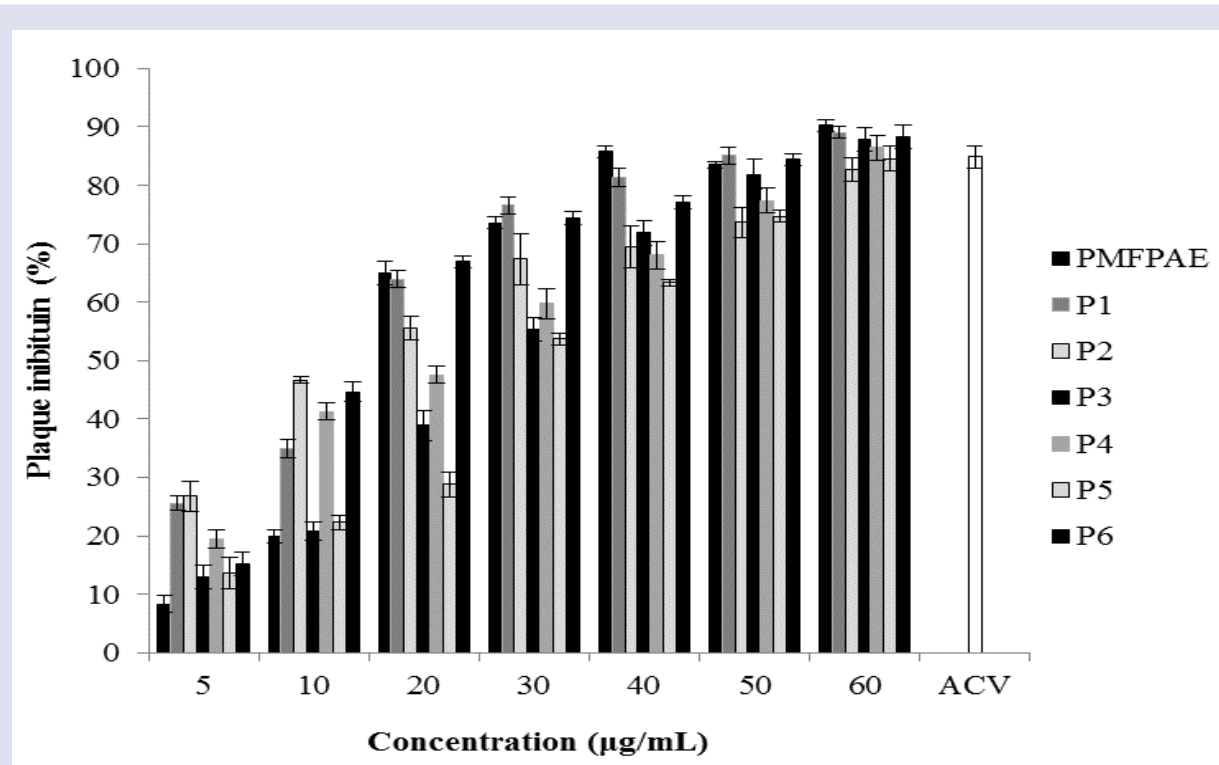

Figure 1: Effect of PMFPAE, $P_{1}$ to $P_{6}$ fractions and acyclovir (ACV) post-treatment on HHV-1 clinical strain. $A C V(4.5 \mu \mathrm{g} / \mathrm{mL})$ was used as the positive control drug. The values are represented as mean $\pm S D(n=3)$.

SI is a ratio between the cytotoxicity towards Vero cells and the effectiveness of the antiviral activity of a substance $\left(\mathrm{CC}_{50} / \mathrm{EC}_{50}\right)$. The SI values of PMFPAE and the fractions is shown in Table 1 were greater than 10 except for $\mathrm{P}_{3}$ and $\mathrm{P}_{4}$. SI values greater than 10 indicates the effectiveness of the extracts or fractions as potential antiviral agents as suggested by Dargan ${ }^{29}$. The SI for PMFPAE in this study is much higher than reported previously using $P$. macrocarpa methanol crude extract, hexane fraction or aqueous extract with the SI values of 17.8, 2.6 and 17.9 respectively ${ }^{7,9,10}$. The trend in reduced antiviral activity with fractionation can also be observed in this study. The SI values decreased in several fractions implicating the need of protein combinations to maintain the synergistic antiviral activity. The distribution of protein within certain fractions $\left(\mathrm{P}_{1}, \mathrm{P}_{2}\right.$ and $\left.\mathrm{P}_{6}\right)$ are also important to maintain high antiviral activity. In phenol extracted $P$. macrocarpa fruit, the total number of proteins identified after analysis by liquid chromatography tandem mass spectrometry (LC-MS/MS) was 680 proteins as reported by Habib \& Ismail ${ }^{12}$. By GFC in this study, relevant proteins with antiviral activity were able to be separated according to the size.

\section{Effect of PMFPAE cell pre-treatment on HHV-1 infection}

PMFPAE with the highest SI value was decided to be further evaluated in the cell pre-treatment activity to determine the prophylactic potential of extract to protect host cells against HHV-1 infection. Pre-treatment of cells with PMFPAE showed approximately $30-42 \%$ of HHV-1 plaque inhibition that was not dose dependent (Figure 2). PMFPAE protect cells but at low levels when treated prior to infection to HHV1 clinical strain. Drug control ACV showed a low plaque inhibition percentage and this is understandable due to its mode of action does not involve prophylactic activity ${ }^{2}$. As a conclusion, PMFPAE display weak prophylactic or cell protecting capabilities against HHV-1 infection.

The effect of cell pre-treatment of $P$. macrocarpa methanol extract, chloroform fraction and ethyl acetate fraction in protecting against HHV-1 infection has been reported previously ${ }^{9}$. Protection against virus infection can be mediated by innate immune response especially interferon to induce an antiviral state ${ }^{30}$. Apoptosis is one of the crucial key players in immune regulation against viral infection. Adaptability to evade this important host defence mechanism is present in HHV1 by blocking pro-apoptotic cell function ${ }^{31}$. Pro-apoptosis and apoptosis capability of $P$. macrocarpa fruit extract been reported against cancer cells such as in MDA-MB-231 cells through intrinsic mitochondrial related pathway with the participation of pro and antiapoptotic proteins, caspases, $G_{0} / G_{1}$ and $G_{2} / M$-phases cell cycle arrest by 553 -mediated mechanism ${ }^{20}$. Whether PMFPAE contains apoptosis promoting material that may control HHV-1 replication is yet to be discovered.

\section{Effect of PMFPAE on HHV-1 replication phases}

PMFPAE that showed highest SI value hence its effect on the replication phases of HHV-1 clinical strain by means of time-addition and timeremoval assays was evaluated. In time-addition assay, PMFPAE at 60 $\mu \mathrm{g} / \mathrm{mL}$ was added to the infected Vero cells with the HHV-1 clinical strain at 2, 4, 6, 8, 10 or 12 hpi. Figure 3 showed that PMFPAE has the highest plaque inhibition percentage towards HHV-1 clinical strain when added after 2 hpi and decreases with time. Less than 50\% 


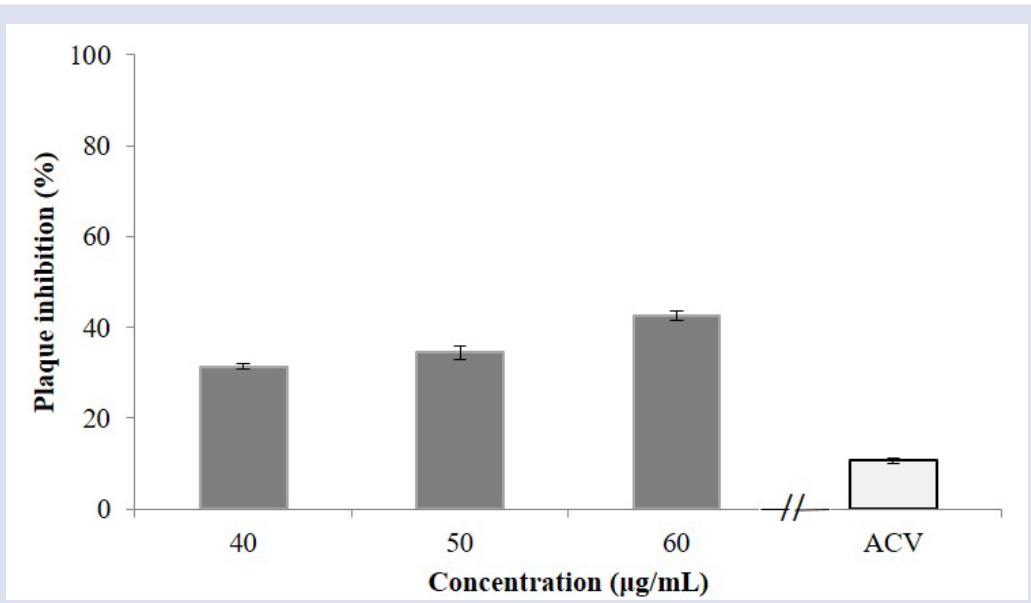

Figure 2: The effect of PMFPAE and acyclovir (ACV, $4.5 \mu \mathrm{g} / \mathrm{mL}$ ) pre-treatment to cells and ability of HHV-1 clinical strain to infect. The values represent as mean $\pm S D(n=3)$.

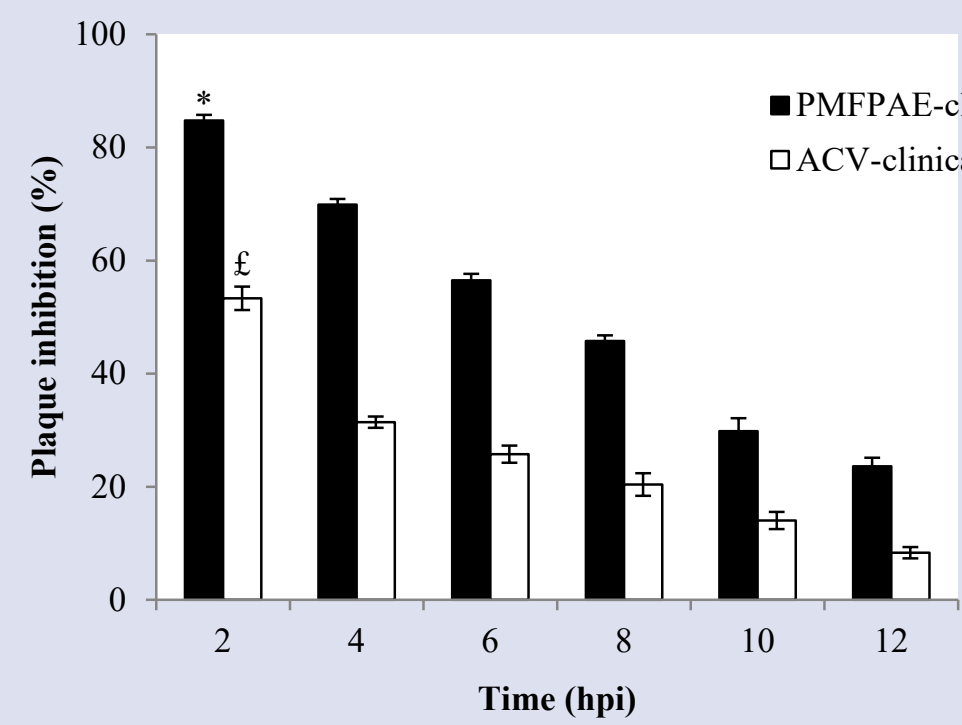

Figure 3: Plaque inhibition percentage versus time-addition of PMFPAE against the HHV-1 clinical strain. PMFPAE at $60 \mu \mathrm{g} /$ $\mathrm{mL}$ was added at $2,4,6,8,10$ or $12 \mathrm{hpi}$ of HHV-1 to Vero cells. Acyclovir (ACV, $4.5 \mu \mathrm{g} / \mathrm{mL}$ ) was used as the positive control drug. ${ }^{*}$ Indicates significant difference between period of PMFPAE addition $(p<0.05)$. ${ }^{\mathrm{f}}$ Indicates significant difference between period of ACV addition $(p<0.05)$. Values represents percentage mean $\pm S D(n=3)$.

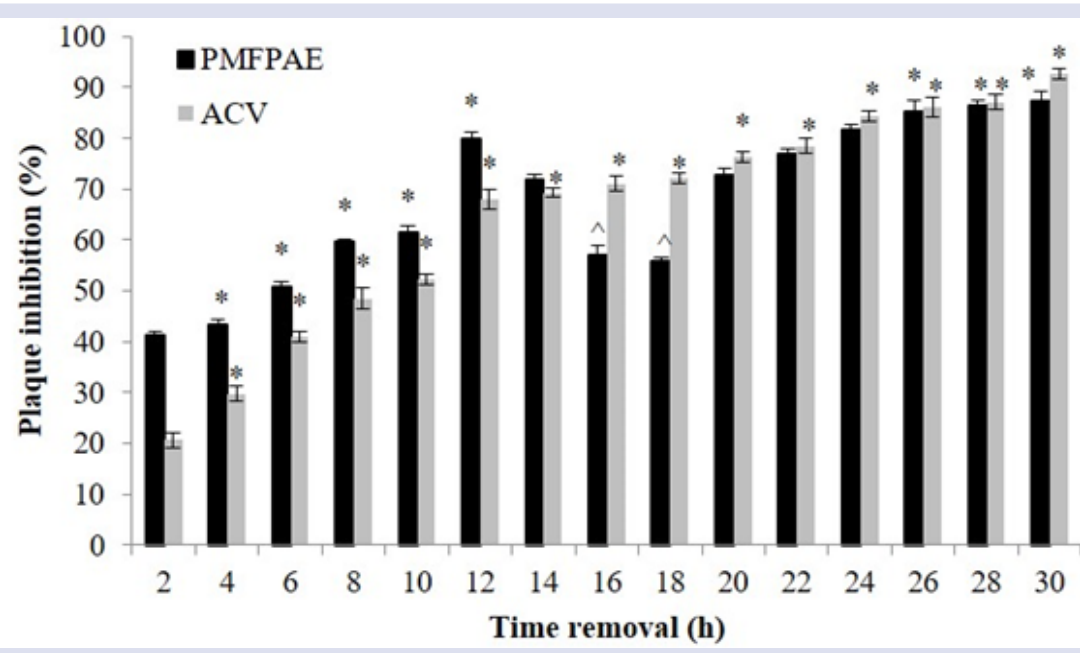

Figure 4: Plaque inhibition percentage versus time-removal of PMFPAE against the HHV-1 clinical strain. "Indicates significant difference compared to shorter exposure time $(p<0.05)$. ^indicates significant difference compared to timeremoval shorter than $8 \mathrm{~h}(\mathrm{p}<0.05)$. The values are represented as the mean $\pm S D(n=3)$. 
plaque reduction percentage was noted after 8 to $12 \mathrm{hpi}$. This similar trend in displaying the antiviral activity during the early stages of the HHV-1 replication cycle has been observed in previous research using P. macrocarpa fruit methanol extract (PMFME) ${ }^{9}$. As for ACV, plaque reduction percentage was lower than PMFPAE. It is known that the ACV mechanism towards HHV-1 is by inhibition of DNA synthesis, which is around the middle phase of replication cycle ${ }^{2}$. However, when $\mathrm{ACV}$ is added beyond $4 \mathrm{hpi}$, ACV was not effective in inhibiting HHV1 DNA synthesis.

In short, PMFPAE acts upon the early replication phase and is still effective until $8 \mathrm{hpi}$. The antiviral activity may still be displayed because PMFPAE can be taken up by the cells and targets viral replication in the immediate-early (IE) or early (E) phase of viral replication. The IE genes and proteins that are expressed as early as $2 \mathrm{hpi}$ would peak in production at 3-4 hpi and reduce around $8 \mathrm{hpi}^{32,33}$.

\section{PMFPAE Effect On HHV-1 In Time-Removal Assay}

Figure 4 shows plaque inhibition percentage of PMFPAE or ACV treatments to infected cells that were removed after 2 to 30 hours of incubation. The percentage of plaque inhibition in the HHV-1 clinical strain increased from $41 \pm 0.6 \%$ to $80 \pm 1.2 \%$ when cells were treated for 2 to $12 \mathrm{hpi}$. Longer treatment (14 to $18 \mathrm{hpi}$ ) with PMFPAE showed decrease in plague inhibition, but the percentage increased again at 20 to $30 \mathrm{hpi}$ from $73 \pm 1.2 \%$ to $87 \pm 2.0 \%$. In this study, from the plaque number of the untreated virus-infected cells, it is estimated that the time for a complete replication cycle of HHV-1 is 16 to $20 \mathrm{~h}$.

Correlating to the time-removal results and according to Ibáñez et al. ${ }^{32}$, expression of immediate early (IE) genes in the viral replication occurs 4-8 hours of post infection. Expression of early (E) genes occurs during $10^{\text {th }}$ to $16^{\text {th }}$ hour post-infection and late $(\mathrm{L})$ genes after 16-24 hours. Therefore, this study indicates that PMFPAE has low effect on IE genes, with moderate to high effect during $\mathrm{E}$ and $\mathrm{L}$ genes expressions. An interesting observation in this study is the plaque inhibition percentage when using PMFPAE throughout the assay is significantly higher than in ACV treated. This observation serves as advantage to PMFPAE for further development in anti-HHV-1 alternatives.

Plaque inhibition percentage for ACV treatment as the positive control in the time-removal-assay was low from 2 to 10 hours. When treated for more than 12 hours, ACV maintains $60 \%$ plaque inhibition percentage until 24 hours and increase to more than $70 \%$ up to 30 hours. It is known that ACV acts upon DNA synthesis which is related to the early phase (E gene) in replication cycle of HHV $-1^{2}$.

\section{CONCLUSION}

Protein from $P$. macrocarpa aqueous extract was not cytotoxic to Vero cell on the host. PMFPAE has antiviral activity against clinical strain of HHV-1 with SI of 80.6, higher than its fractions $\left(\mathrm{P}_{1}\right.$ to $\left.\mathrm{P}_{6}\right)$. Pretreatment with PMFPAE towards cells does not fully protect against HHV-1 infection. The effect of PMFPAE is more obvious during immediate-early and late phases of HHV-1 replication. Further studies need to be done to explore the antiviral mechanism of PMFPAE in detail for potential therapeutic alternative for HHV-1.

\section{ACKNOWLEDGEMENTS}

The research was supported by the Ministry of Higher Education Malaysia (Grant number FRGS/1/2019/WAB11/UKM/02/1).

\section{CONFLICTS OF INTEREST}

None.

\section{ABBREVIATIONS}

ACV; CC $_{50}$ DMEM; EC 50 ;FC; HHV-1; hpi; FBS; MC; MTT; pfu; PMFPAE; SI.

\section{REFERENCES}

1. James C, Harfouche M, Welton NJ, Turner KM, Abu-Raddad LJ, Gottlieb SL, et al. Herpes simplex virus: global infection prevalence and incidence estimates, 2016. B World Health Organ. 2020;98(5):315-29.

2. Gnann JW Jr, Barton NH, Whitley RJ. Acyclovir: mechanism of action, pharmacokinetics, safety and clinical applications. Pharmacotherapy. 1983;3(5):275-83. doi: 10.1002/j.18759114.1983.tb03274.x.

3. Piret J, Boivin G. Resistance of herpes simplex viruses to nucleoside analogues: mechanisms, prevalence, and management. Antimicrob Agents Chemother. 2011;55 (2):459-72. doi: 10.1128/AAC.00615-10.

4. Bacon TH, Levin MJ, Leary JJ, Sarisky RT, Sutton D. Herpes simplex virus resistance to acyclovir and penciclovir after two decades of antiviral therapy. Clin Microbiol Rev. 2003;16(1):114-28. doi: 10.1128/CMR.16.1.114-128.2003.

5. Str'ansk'a R, Schuurman R, Nienhuis E, Goedegebuure IW, Polman $M$, Weel JF. et al. Survey of acyclovir-resistant herpes simplex virus in the Netherlands: prevalence and characterization. J Clin Virol. 2005;32(1):7-18. doi: 10.1016/j.jcv.2004.04.002.

6. Jiang $Y$, Feng $H$, Lin $Y$, Guo $X$. New strategies against drug resistance to herpes simplex virus. Int J Oral Sci. 2016:8:1-6. doi:10.1038/ijos.2016.3.

7. Tahir MM, Ibrahim N, Yaacob WA. Cytotoxicity and antiviral activities of Asplenium nidus, Phaleria macrocarpa and Eleusine indica. AIP Conf Proc. 2014;1614:549-52. doi: 10.1063/1.4895259

8. Ismaeel MYY, Yaacob WA, Tahir MM, Ibrahim N. Phytochemical screening, cytotoxicity and antiviral activity of hexane fraction of Phaleria macrocarpa fruits. AIP Conf Proc. 2015;1678:030012. doi: 10.1063/1.4931233.

9. Ismaeel M, Dyari, HRE, Nor NSM, Yaacob WA, Ibrahim, N. Antihuman herpesvirus type-1 activity of Phaleria macrocarpa fruits methanol extract and fractions. Malays Appl Biol 2018;47(5):31-40.

10. Ismaeel MYY, Dyari HRE, Yaacob WA, Ibrahim N. In vitro antiviral activity of aqueous extract of Phaleria macrocarpa fruit against herpes simplex virus type 1. AIP Conf Proc. 2018;1940:020076.

11. Lay MM, Karsani SA, Mohajer S, Abd Malek SN. Phytochemical constituents, nutritional values, phenolics, flavonols, flavonoids, antioxidant and cytotoxicity studies on Phaleria macrocarpa (Scheff.) Boerl fruits. BMC Complem Altern Med. 2014;14:152. doi:10.1186/1472-6882-14-152.

12. Habib MAH, Ismail MN. Extraction and identification of biologically important proteins from the medicinal plant God's crown (Phaleria macrocarpa). J Food Biochem. 2021;45(7): e13817. doi.org/10.1111/ jfbc.13817.

13. Sun J, Su Y, Wang T. Expression, purification and identification of $\mathrm{CtCVNH}$, a novel anti-HIV (human immunodeficiency virus) protein from Ceratopteris thalictroides. Int J Mol Sci. 2013;14(4);7506-14. doi: 10.3390/ijms14047506.

14. Thepouyporn A, Yoosook C, Chuakul W, Thirapanmethee K, Napaswad C, Wiwat C. Purification and characterization of antiHIV-1 protein from Canna indica leaves. SE Asian J Trop Med. 2012;43(5);1153-60. PMID: 23431821

15. Dutt S, Yadav OP, Kapoor H, Lodha ML. Possible mechanism of action of antiviral proteins from the leaves of Chenopodium album L. Indian J Biochem Biophys. 2004;41(1):29-33. PMID: 22896905

16. Ali RB, Atangwho IJ, Kuar N, Mohamed EA, Mohamed AJ, Asmawi $\mathrm{MZ}$ et al. Hypoglycemic and anti-hyperglycemic study of Phaleria macrocarpa fruits pericarp. J Medic Plants Res. 2012;6(10):198290. doi: 10.5897/JMPR11.1683

17. Altaf R, Asmawi MZ, Dewa A, Sadikun A, Umar MI. Phytochemistry and medicinal properties of Phaleria macrocarpa (Scheff.) Boerl. extracts. Pharmacogn Rev. 2013;7(13):73-80. doi: 10.4103/09737847.112853. 
18. Hendra R, Ahmad S, Oskoueian E, Sukari A, Shukor MY. Antioxidant, anti-inflammatory and cytotoxicity of Phaleria macrocarpa (Boerl.) Scheff Fruit. BMC Complem Altern Med. 2011;11:110. doi: 10.1186/1472-6882-11-110.

19. Sumarawati T, Riwanto I, Hadisaputro S, Dharmana E, Nasihun T. Effect of Phaleria macrocarpa on atrophy and apoptosis of intestinal mucous cell and phalerin concentration at portal vein and systemic circulation in adenocarcinoma mice following adriamycine and cyclophosphamide treatment. Pharmacog J. 2020;12(3):603-10. doi: 10.5530/pj.2020

20. Kavitha N, Ein Oon C, Chen Y, Kanwar JR, Sasidharan S. Phaleria macrocarpa (Boerl.) fruit induce $\mathrm{G}_{0} / \mathrm{G}_{1}$ and $\mathrm{G}_{2} / \mathrm{M}$ cell cycle arrest and apoptosis through mitochondria-mediated pathway in MDAMB-231 human breast cancer cell. J Ethnopharmacol. 2017;201:4255. doi: 10.1016/j.jep.2017.02.041. PMID: 28263848.

21. Rehman S., Khanum A. Isolation and characterization of peptide (s) from Pisum sativum having antimicrobial activity against various bacteria. Pak J Bot. 2011;43:2971-8.

22. Bradford MMA. 1976. Rapid and sensitive method for the quantitation of microgram quantities of protein utilizing the principle of protein-dye binding. Anal Biochem. 1976; 72:248-54. doi: 10.1006/abio.1976.9999.

23. Iberahim R, Nor NSM, Yaacob WA, N Ibrahim. Eleusine indica inhibits early and late phases of herpes simplex virus type 1 replication cycle and reduces progeny infectivity. Sains Malays. 2018;47(7):1431-8. doi: 10.17576/jsm-2018-4707-10.

24. Wu X, Gong F, Wang W. Protein extraction from plant tissues for $2 \mathrm{DE}$ and its application in proteomic analysis. Proteomics 2014;14(6):645-58.

25. Ooi LS, Sun SS, Ooi VE. Purification and characterization of a new antiviral protein from the leaves of Pandanus amaryllifolius (Pandanaceae). Int J Biochem Cell Biol. 2004;36(8):1440-6. doi: 10.1016/j.biocel.2004.01.015.
26. Castel G, Chteoui M, Heyd B, Tordo N. Phage display of combinatorial peptide libraries: application to antiviral research. Molecules. 2011;16:3499-518. doi: 10.3390/molecules16053499.

27. Vijayarathna S., Sasidharan, S. Cytotoxicity of methanol extracts of Elaeis guineensis on MCF-7 and Vero cell lines. Asian Pac. J. Trop. Biomed. 2012;2(10):826-9. doi: 10.1016/S2221-1691(12)60237-8.

28. Andrighetti-Fröhner CR, Antonio RV, Creczynski-Pasa TB, Barardi CRM, Simões CMO. Cytotoxicity and potential antiviral evaluation of violacein produced by Chromobacterium violaceum. Memórias do Instituto Oswaldo Cruz. 2003;98(6):843-8. doi: 10.1590/s007402762003000600023 .

29. Dargan DJ. Investigation of the anti-HSV activity of candidate antiviral agents. Methods Mol Med. 1998;10:387-405. doi: 10.1385/0-89603-347-3:387. PMID: 21374243

30. 30.Katze $M, \mathrm{He} Y$, Gale $M$. Viruses and interferon: a fight for supremacy. Nat Rev Immunol. 2002;2:675-87. doi: 10.1038/ nri888.

31. Jerome KR, Chen Z, Lang R, Torres MR, Hofmeister J, Smith S. et al. HSV and glycoprotein inhibit caspase activation and apoptosis induced by granzyme b or fas. J Immunol. 2001;1:3928-35. DOI: 10.4049/jimmunol.167.7.3928

32. Ibáñez FJ, Farías MA, Gonzalez-Troncoso MP, Corrales N, Duarte LF, Retamal-Díaz A. et al. Experimental dissection of the lytic replication cycles of herpes simplex viruses in vitro. Front Microbiol. 2018:9:2406. doi: 10.3389/fmicb.2018.02406.

33. Phelan A, Carmo-Fonseca M, McLaughlan J, Lamond Al, Clements JB. A herpes simplex virus type 1 immediate-early gene product, IE63, regulates small nuclear ribonucleoprotein distribution. Proc Nat Acad Sci. 1993;90(19):9056-60. doi: 10.1073/ pnas.90.19.9056.

\section{GRAPHICAL ABSTRACT}

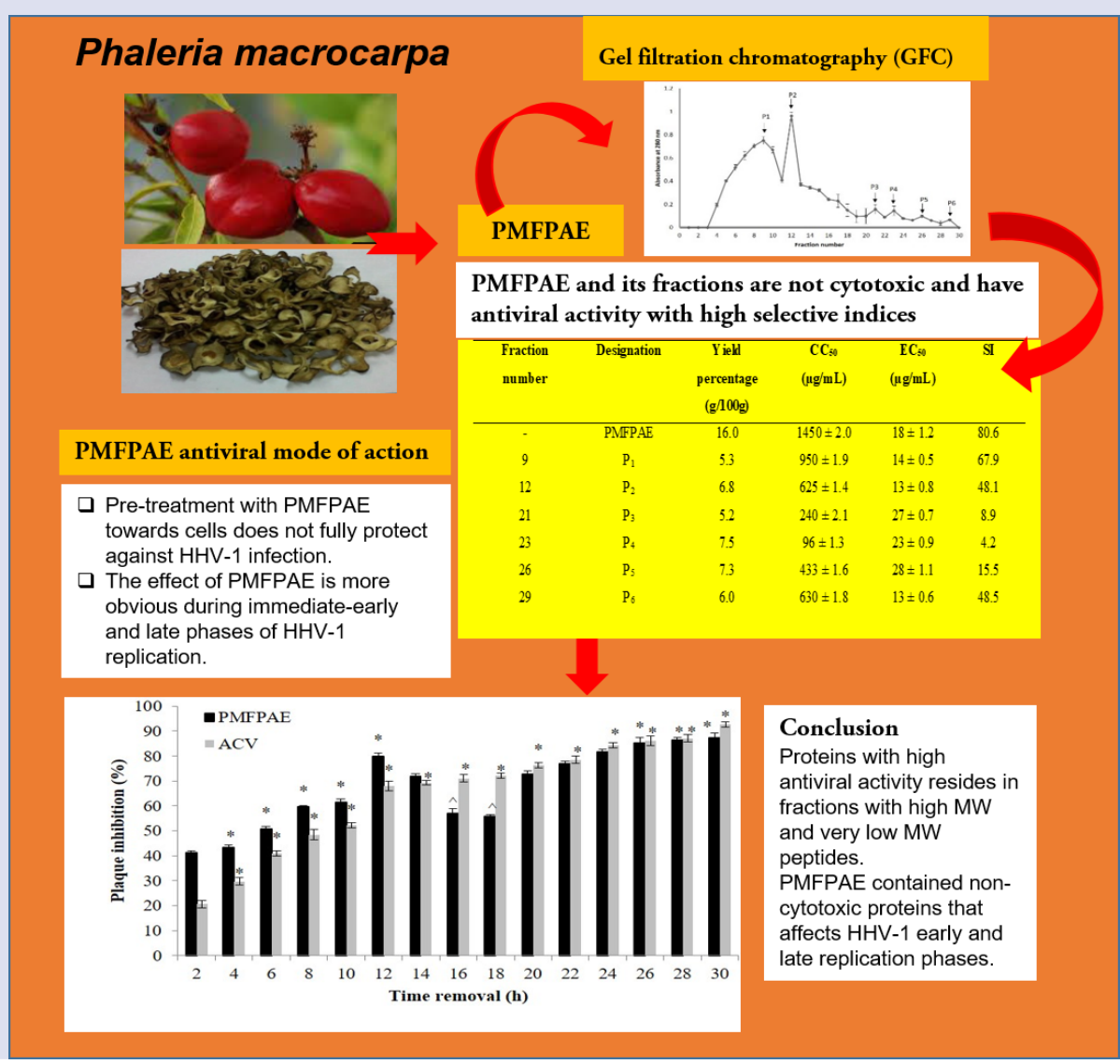




\section{ABOUT AUTHORS}

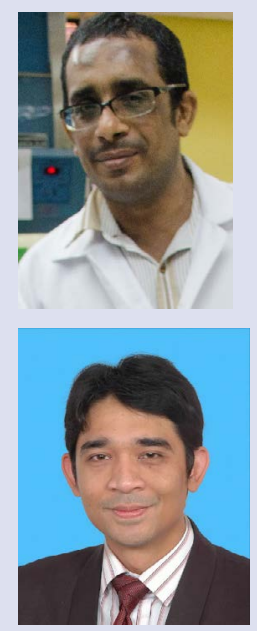

Mr. Mahmud Yusef Yusef Ismaeel graduated from Universiti Kebangsaan Malaysia (UKM) with Master's Degree in Microbiology. He is currently pursuing his postgraduate studies reading for a PhD at the Department of Biological Sciences and Biotechnology, UKM.

Dr. Herryawan Ryadi Bin Eziwar Dyari is a senior lecturer in the Department of Earth and Environmental Sciences, Faculty of Science and Technology, UKM. His current research interest is to understand the interaction of cells with their environment.

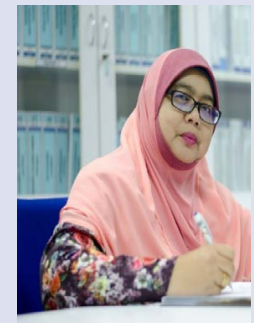

Associate Professor Dr. Nazlina Ibrahim is a senior lecturer at the Department of Biological Sciences and Biotechnology, Faculty of Science and Technology, Universiti Kebangsaan Malaysia. Her current research interest is in understanding the anti-microbial activities of local plants, endophytes and synthetic chemicals.

Cite this article: Ismaeel MYY, Dyari HRE, Ibrahim N. Protein from Phaleria macrocarpa Fruit Aqueous Extract Inhibits Early and Late Replication Phases of Human Herpes Virus Type-1. Pharmacogn J. 2022;14(1): 39-45. 